\title{
Macroalgal canopies: distribution and diversity of associated invertebrates and effects on the recruitment and growth of mussels
}

\author{
Chantale Bégin, Ladd E. Johnson*, John H. Himmelman \\ Département de biologie et Québec-Océan (GIROQ), Université Laval, Québec, Québec G1K 7P4, Canada
}

\begin{abstract}
We examined the invertebrate assemblages associated with macroalgal canopies in the Mingan Islands (northern Gulf of St. Lawrence, eastern Canada) in the summer and fall of 2001. Invertebrates were sampled in patches or beds of 4 species of macroalgae (Alaria esculenta, Agarum cribrosum, Desmarestia viridis and Ptilota serrata) as well as in adjacent urchin barrens. Multivariate analyses of the invertebrates on the algal fronds, those on the underlying substratum, and the 2 groups together demonstrated differences in invertebrate assemblages among all 5 habitats. $A$. esculenta sheltered the most distinct invertebrate community due to the domination of the substratum under this alga by the blue mussel Mytilus edulis. Differences among other canopy types were due to differences in invertebrate assemblages both on the algal fronds and on the substratum. A manipulative experiment involving the removal of the canopy of the 2 most abundant macroalgae, A. esculenta and A. cribrosum, was carried out to examine their effects on mussels. Recruitment of mussels onto ceramic tiles varied among treatments and was greatest in the A. esculenta zone with greater, but non-significant, recruitment under the canopy. The growth of mussels from early July to October was higher in the A. cribrosum zone than the A. esculenta zone. However, there was no effect of the algal canopy in either zone. Our study demonstrates that the local diversity and distribution of benthic invertebrates is intimately associated with macroalgae, and reinforces the need for detailed sampling and analyses for assessing distributional patterns.
\end{abstract}

KEY WORDS: Biodiversity $\cdot$ Community structure $\cdot$ Ecosystem engineering $\cdot$ Kelp bed $\cdot$ Mytilus edulis $\cdot$ Positive interactions

\section{INTRODUCTION}

Experimental studies of interactions between animals and plants have traditionally focused on herbivory (Lubchenco \& Gaines 1981), but there is growing interest in understanding non-trophic, positive interactions among species (Bertness \& Callaway 1994, Bertness \& Leonard 1997, Hacker \& Gaines 1997, Jones et al. 1997, Bertness et al. 1999). In the marine environment, macroalgae are a conspicuous part of intertidal and subtidal marine communities and have important influences on coexisting species (Duggins et al. 1990, Irlandi \& Peterson 1991, Bulleri et al. 2002). Large macrophytes add physical complexity to the substra- tum and can increase species richness and diversity (Gilinsky 1984, Dean \& Connell 1987c) through a number of interrelated mechanisms. Macrophytes can provide new habitat for epibiota and are a source of food for herbivores feeding on them, or filter feeders benefiting from the release of organic matter (Duggins et al. 1989) and spores (Santelices \& Martinez 1988). Macroalgae can also produce chemicals that induce or deter colonization by invertebrates (Steinberg \& de Nys 2002). Macrophytes can affect understorey assemblages by modifying physical factors such as light (Kennelly 1989) and water flow (Duggins et al. 1990), by scouring the substratum with algal fronds (Velimirov \& Griffiths 1979, Kennelly 1989), and by redu- 
cing the density or efficiency of predators (Menge 1978, Peterson 1982, Duffy \& Hay 1991, Eckman \& Duggins 1991, Irlandi \& Peterson 1991, Gagnon et al. 2003b). Changes in the hydrodynamic regime under canopies can modify larval supply and settlement (Eckman 1983), and the modification of physical factors (light, sedimentation) under canopies may affect the survival of recruits (Young \& Chia 1984). Changes in flow under canopies may also modify the growth and survival of filter feeders (Eckman \& Duggins 1991), as feeding activities have been shown to be influenced by current velocity (Fréchette \& Bourget 1985a, Wildish \& Miyares 1990, Leichter \& Witman 1997, Archambault \& Bourget 1999).

Macroalgal canopies therefore provide a different physical and biological environment than adjacent areas lacking such cover. The nature and extent of the impact of canopies likely varies with algal morphology and longevity. For example, increased structural complexity of algal fronds increases abundance and diversity of small invertebrates living on them (e.g. Dean \& Connell 1987c, Hacker \& Steneck 1990, Taylor \& Cole 1994). Moreover, if colonization rates are time-dependent, perennial macroalgae may have a greater impact on invertebrate species-composition and diversity than shortlived algae by creating more persistent habitat patches.

Marine macrophytes are a ubiquitous feature of temperate subtidal environments and their local distribution depends on numerous physical and biological factors. In the western North Atlantic, grazing by the green urchin Strongylocentrotus droebachiensis is an important factor in the suppression of macroalgae and maintenance of patchiness (Himmelman 1984, Dayton 1985, Witman 1987, Scheibling et al. 1999). Removal of sea urchins experimentally (Himmelman et al. 1983) or naturally (Scheibling 1986, Johnson \& Mann 1993) causes rapid increases in macroalgal abundance. Disturbance by storms (Dayton et al. 1984, Kennelly 1987) and ice scour at higher latitudes (Keats et al. 1985) can also eliminate parts of shallow algal beds and thereby maintain patchiness.

In the Mingan Islands in the northern Gulf of St. Lawrence, eastern Canada, the green urchin is extremely abundant and forms extensive urchin barrens largely devoid of erect macroalgae. Large kelps, Alaria esculenta and Laminaria digitata, are abundant in shallow water but are excluded from deeper areas by urchin grazing (Gagnon et al. 2004). Below this limit, less preferred macroalgae, notably Agarum cribrosum, Desmarestia viridis and Ptilota serrata, occur in patches of varying size. The physical and biological environment therefore varies considerably on a small scale (meters), and this variability in algal habitats may directly affect the abundance, survival and growth of various invertebrates.
This study compared invertebrate communities found in association with the different subtidal habitats in the Mingan Islands to determine how each type of macroalgal canopy might influence the assemblage of invertebrates associated with their fronds and those found on the bottom under the fronds. This stratified sampling (i.e. invertebrates on the algal fronds and on the bottom separately) and the use of multivariate and univariate analyses allowed us to characterize how different assemblages of invertebrates were associated with macroalgae canopies, both in terms of location (bottom vs canopy) and specific species. We further used field manipulations to examine the effect of these canopies on the growth and recruitment of a dominant, filter-feeding invertebrate associated with the bottom, the mussel Mytilus edulis.

\section{MATERIALS AND METHODS}

Study site. Observations and experiments were carried out from June to October 2001 in the Mingan Islands, in the northern Gulf of St. Lawrence. Extensive urchin Strongylocentrotus droebachiensis barrens are found on most shallow rocky subtidal areas in this region and the distribution of macroalgae is patchy (Himmelman 1991). The most abundant algal patches consist of Alaria esculenta, Agarum cribrosum, Desmarestia viridis and Ptilota serrata, which usually form mono-specific stands. A. esculenta is a large (up to $2 \mathrm{~m}$ ) perennial kelp that forms a distinct zone in shallow water (usually at depths $<3 \mathrm{~m}$ ), and its lower limit (at greater depths on the exposed side of the islands) is determined by urchin grazing (Gagnon et al. 2004). The short flexible stipe of $A$. esculenta permits the long, narrow frond to sweep back and forth with the water movement. Another perennial kelp, Laminaria digitata, occurs in much lower numbers within the A. esculenta zone. Within the urchin barrens, other algae that are less preferred as food by urchins (A. cribrosum, D. viridis and P. serrata; Himmelman \& Nédélec 1990) occur in patches of various sizes. The perennial kelp A. cribrosum (ca. $1 \mathrm{~m}$ height) is found in patches that vary in size from a few meters to over $100 \mathrm{~m}$ in length at depths of 3 to $12 \mathrm{~m}$. Its somewhat rigid stipe holds its thick, perforated blade mostly off the bottom. The branched annual brown alga $D$. viridis occurs at depths of 7 to $10 \mathrm{~m}$ and forms small patches (generally $<4 \mathrm{~m}^{2}$ ) consisting of 1 to several individuals 0.4 to $0.7 \mathrm{~m}$ in length. $D$. viridis has a short flexible stipe, and the blade branches profusely into fine filaments so that the alga sweeps back and forth with the slightest water movement (Gagnon et al. 2003a). Finally, the perennial red alga $P$. serrata occurs at depths of 8 to $15 \mathrm{~m}$. The bushy thallus, usually 10 to 
$15 \mathrm{~cm}$ in length, consists of primary branches and short branchlets. The fronds form dense turfs that occur either under A. cribrosum or alone (usually at greater depths).

Invertebrates in algal habitats and barrens. We sampled in July and August 2001 around 4 islands (Ile aux Goélands, Ile à Calculot, Petite Ile au Marteau, and Ile du Havre) to characterize invertebrate communities associated with the 4 types of algal canopies (Alaria esculenta, Agarum cribrosum, Desmarestia viridis and Ptilota serrata) and with urchin barrens. For each community type, we used SCUBA to collect all invertebrates in 3 haphazardly selected $0.25 \mathrm{~m}^{2}$ quadrats at each of 4 sites. We did not necessarily sample all types of algal canopies for each island as it was sometimes difficult to find all 4 habitats within close proximity, and thus some habitats were sampled at more than one site around an island.

Because we were interested in distinguishing between benthic invertebrates directly associated with the algae (henceforth 'invertebrates on the algae') and those associated with the underlying substratum (henceforth 'invertebrates on the bottom'), we employed a stratified sampling approach for each quadrat. We first carefully placed all visible fleshy macroalgae, including holdfasts, and associated invertebrates in a $1 \mathrm{~mm}$ mesh bag. Macroinvertebrates on the bottom were then removed and placed in a sealed plastic bag. Finally, all other invertebrates were scraped from the bottom and transferred to $1 \mathrm{~mm}$ mesh bags using a suction sampler. In this way, we collected all invertebrates larger than $1 \mathrm{~mm}$ except some highly mobile amphipods (general notes on the abundance of amphipods were still taken, but these data were excluded from analyses due to inconsistent sampling). Within $24 \mathrm{~h}$, all invertebrates on the algae and on the bottom were identified to the lowest taxon possible, counted and weighed.

For each sample, the Shannon diversity index was calculated for (1) invertebrates on the algae, (2) invertebrates on the bottom, and (3) both groups combined. Differences in diversity among the 5 habitats (the 4 types of algal canopies and urchin barrens) were assessed using a 1-way ANOVA followed by Ryan's test (Day \& Quinn 1989). Similarity of invertebrate assemblages among the 5 habitats was determined using non-metric multidimensional scaling with the Bray-Curtis similarity index based on abundance and biomass, using a square-root transformation. We tested for differences in species assemblages between habitats using the ANOSIM permutation test (Clarke 1993), followed by the SIMPER routine to identify which species were responsible for the similarity within habitats and dissimilarity between habitats. One-way ANOVAs were conducted on species that contributed to dissimi- larity between habitats (at least $2 \%$, as determined by SIMPER) to test for an effect of algal canopies on abundance. Data were ranked prior to performing ANOVA to remove heterogeneity of variance (resulting in a test equivalent to the nonparametric Kruskal-Wallis test Conover 1971), and Ryan's test was performed a posteriori. Multivariate analyses were conducted using PRIMER 5.2.8 (Primer-E) and univariate analyses using SAS 8.02 (SAS Institute).

Effect of canopy removal on mussel growth and recruitment. We examined the effect of algal canopies on mussel recruitment and growth by experimentally removing the canopies of Alaria esculenta and Agarum cribrosum, the 2 most abundant macroalgae. At each of 2 sites, Ile aux Goélands and Ile à Calculot, where these algae formed extensive stands (up to $100 \mathrm{~m}$ in length for A. cribrosum, more for A. esculenta), we selected six $2 \times 2$ m areas within the canopy of $A$. esculenta (in shallow water) and 6 areas within the canopy of A. cribrosum (at greater depth) in June 2001. All experimental units were separated by at least $10 \mathrm{~m}$. The 6 areas were grouped into 3 blocks of 2 areas. Within each block, one area was randomly selected for the hand removal of the canopy species (including holdfasts), and the other was left undisturbed as a control. For each block in the $A$. cribrosum zone, an additional $2 \times 2 \mathrm{~m}$ area was also selected and marked within the adjacent natural urchin barrens. We could not make parallel observations in A. esculenta zone due to the lack of such a habitat there ( $A$. esculenta generally forms a continuous zone except in areas recently scoured by ice). Thus, a total of 5 treatments were established, 3 in the deeper $A$. cribrosum zone (natural canopy, canopy removal and urchin barrens) and 2 in the shallower $A$. esculenta zone (natural canopy and canopy removal). Because of the different number of treatment levels for each species (3 in A. cribrosum zone and 2 in A. esculenta zone), we performed a 1-way ANOVA with 5 treatment levels, as a balanced 2-way ANOVA was not possible. Blocking was ignored in the analysis, and we assumed that there was no interaction between blocking and treatment.

The above experimental units were used for 2 simultaneous experiments on the growth and recruitment of the mussel Mytilus edulis. To compare the hydrodynamic milieu between treatments, water velocities were measured in one experimental unit of each treatment on 18 June 2002 using a Vector current meter (Nortek AS, see www.nortek-as.com) that sampled the current approximately $10 \mathrm{~cm}$ from the bottom. Measurements were taken continuously (8 readings per second) for $4 \mathrm{~min}$ in each treatment, close to low tide (i.e. during a time of low currents).

Because the mussel Mytilus edulis appeared to have a dominant effect on species diversity in the habitats 
sampled (see 'Results'), we experimentally compared how 2 key demographic processes, mussel growth and recruitment, were affected by the algal canopy in both the Alaria esculenta and the Agarum cribrosum zones. To examine the effect of the algal canopies on the growth of $M$. edulis, we measured increases in shell length and total out-of-water mass (after being blotted dry) for individually tagged mussels placed in the above 5 treatments from 13 July to 30 October 2001. We used small mussels $(1$ to $1.5 \mathrm{~cm}$ ) to assure high rates of somatic growth and minimal gonadal investment. Mussels were collected from the shallow subtidal zone around Ile aux Goélands and Ile du Havre and were tagged with numbered plastic bee tags (Queen marking kit, The Bee Works) glued to the center of one valve. To prevent losses, especially from predation by sea stars, the mussels were placed in the field in $0.5 \mathrm{~cm}$-mesh galvanized wire cages attached to $14 \times$ $14 \mathrm{~cm}^{2}$ bottoms of unglazed ceramic tiles. The mussels were allowed to attach to the tiles over several days in the laboratory before attaching the cages to the bottom in the experimental units in the field with marine epoxy putty (Z-spar Splash Zone Compound). Each cage contained 20 tagged mussels along with an additional 20 untagged mussels. The additional mussels enhanced attachment to the tiles and increased the density to a level closer to those found in nature (up to $10000 \mathrm{~m}^{-2}$ for small mussels; Gaymer et al. 2001). Differences in growth rates between treatments were analyzed by applying 1-way ANOVA to the mean change per cage (for length and weight), and planned contrasts were used to test for differences between urchin barrens and the 4 other treatments, between the 2 zones (A. esculenta and A. cribrosum), and between the presence and absence of a canopy (for both A. esculenta and A. cribrosum).

To examine the effect of canopies on recruitment, we compared the recruitment of invertebrates onto ceramic tiles placed in the above 5 treatments for a 4 mo period ( 27 or 28 June to 30 October). These ceramic tiles were different from those used in the cages for mussel growth experiments. To collect organisms with different substratum preferences (different degrees of shading and protection), each sampling unit consisted of 2 ceramic tiles, one on top of the other, separated by a $1 \mathrm{~cm}$ gap. The tiles were glued together (using spacers in each corner) and attached to the bottom using marine epoxy putty ( 2 sampling units for each $2 \times 2 \mathrm{~m}$ experimental unit). The tiles were recovered from the field in late October and placed in $4 \%$ formaldehyde until analyzed. The invertebrates were identified and counted on 3 surfaces: the upper and lower surfaces of the top plate and upper surface of the bottom plate. Differences in recruitment between treatments were analyzed by a combination of multivariate and univariate methods. As most of the species that recruited were cryptic fouling organisms (e.g. bryozoans, spirorbid polychaetes) that were not found in the benthic samples, we report only the recruitment of the mussel Mytilus edulis in this paper (see Bégin 2002 for the analyses showing differences between treatments in the recruitment of other invertebrates). Mussel recruitment (mussels $<2 \mathrm{~mm}$ in length) was analyzed using a 1-way ANOVA applied to the overall abundance (all surfaces of the recruitment plates together), since these organisms were loosely attached and were often detached from the substratum during the retrieval of the tiles. Data were ranked prior to the ANOVA to remove heterogeneity of variance. Comparisons were carried out using planned orthogonal contrasts as for the analyses of mussel growth. Analyses were done using SAS 8.02.

\section{RESULTS}

\section{Invertebrates in algal habitats and urchin barrens}

There were significant differences in diversity among habitats, for invertebrates on algal fronds $\left(F_{3,28}=6.91, \mathrm{p}=0.0013\right)$, those on the bottom $\left(F_{4,43}=\right.$ $150.91, \mathrm{p}<0.0001)$, and for all invertebrates together $\left(F_{4,43}=27.94, \mathrm{p}<0.0001\right.$; Fig. 1$)$. The Alaria esculenta habitat supported the lowest diversity for bottom and total invertebrates. For invertebrates on algal fronds, Desmarestia viridis had a significantly lower diversity than the other algae.

The multivariate analyses of the invertebrates sampled in the different algal canopies showed that the invertebrate assemblages were distinct in the 5 habitats studied. Abundance and biomass data showed very similar trends; for conciseness only the abundance data are presented here (see Bégin 2002 for biomass data). Multi-dimensional scaling analysis (MDS) of the overall invertebrate community showed clear clusters for the 5 habitats studied, with the Alaria esculenta habitat being the most distinct (Fig. 2). Data points for Desmarestia viridis fell as a tight group within the urchin barren samples. The ANOSIM analysis of the underlying data showed significant differences between every pair of habitats $(p<0.002)$. In the MDS analysis of only the invertebrates on the bottom, the $A$. esculenta samples again showed a cluster far from the other samples. The samples from the other habitats overlapped to varying degrees (Fig. 2); nevertheless, the ANOSIM analysis of the underlying data still showed significant differences between every pair of habitats $(p<0.008)$. When the MDS analysis was applied to just the invertebrates found on algal fronds, the 4 algal types formed distinct clusters with little 

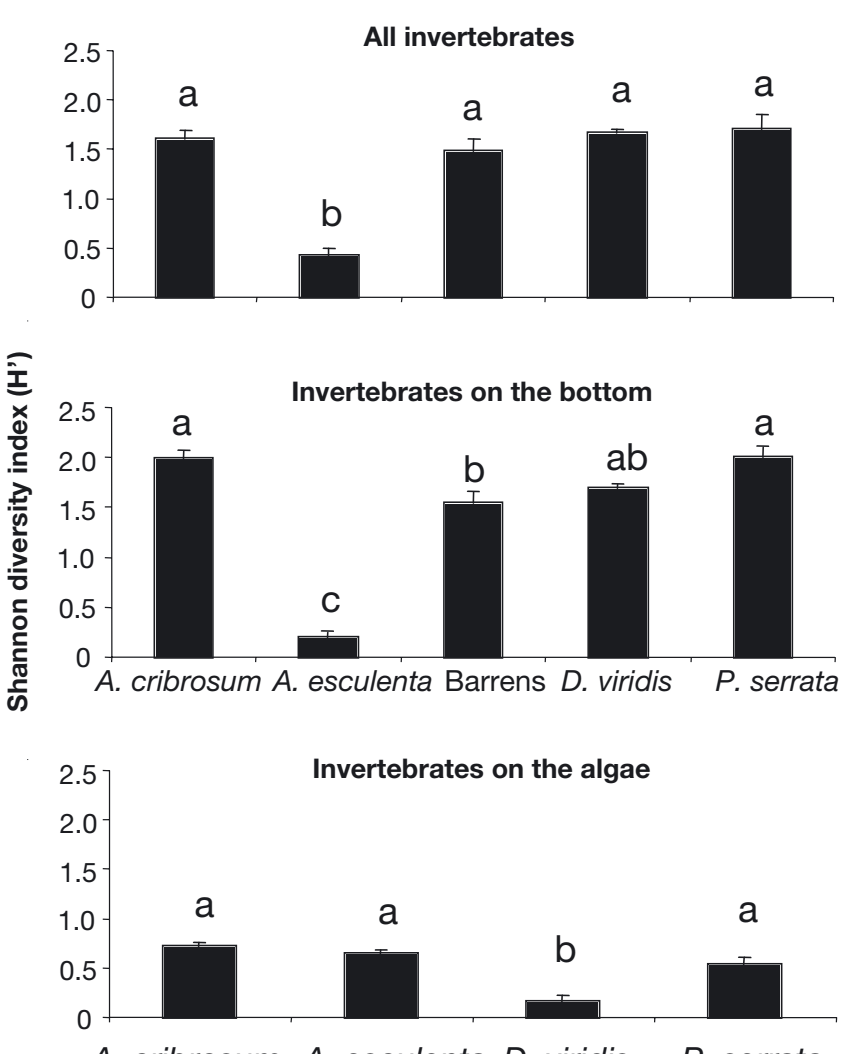

A. cribrosum A. esculenta $D$. viridis $P$. serrata

Fig. 1. Shannon diversity index for all invertebrates associated with the canopies of Agarum cribrosum, Alaria esculenta, Desmarestia viridis and Ptilota serrata, and for the invertebrates occurring on the algae and on the bottom separately. Habitats with the same letter are not significantly different (Ryan's test). Vertical bars represent SEs; $\mathrm{n}=12$ for all treatments, except $P$. serrata $(\mathrm{n}=11)$

overlap between them (Fig. 2), and there were significant ANOSIM differences between every pair ( $\mathrm{p}<$ 0.001). Alaria esculenta and Agarum cribrosum samples fell closest together, whereas the samples from Ptilota serrata and $D$. viridis were well separated.

The SIMPER analysis identified the species most important in causing community differences among habitats. In the analysis of invertebrates on the bottom (Table 1), the blue mussel Mytilus edulis contributed at least $89 \%$ of the dissimilarity of Alaria esculenta from the other habitats. The other 4 habitats were more similar, but the relative abundances of brittle stars Ophiopholis aculeata, urchins Strongylocentrotus droebachiensis, chitons Tonicella marmorea, burrowing clams Hiatella arctica and scaleworms (Polynoidae) were important in creating differences among habitats. Furthermore, several species were found only in 1 or 2 habitats. For example, the mussel Musculus discors laevigatus was found mainly in association with
All Invertebrates

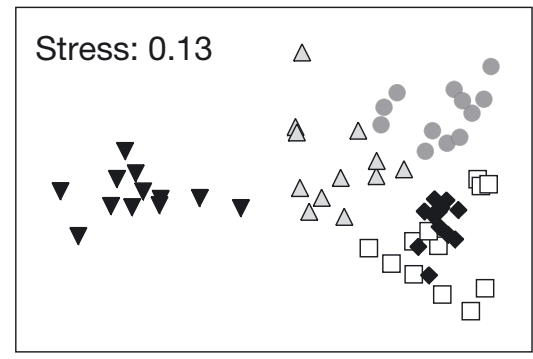

Invertebrates on the bottom

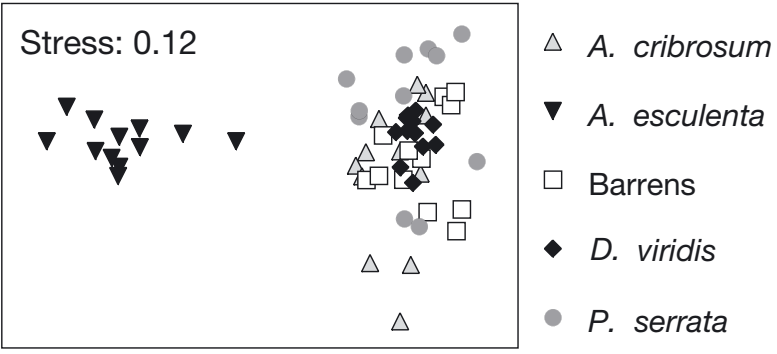

Invertebrates on algal fronds

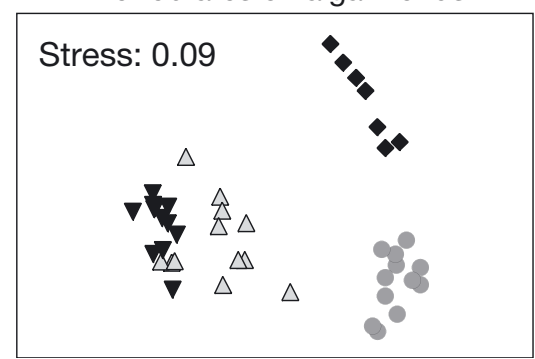

Fig. 2. Non-metric multidimensional scaling plots for all invertebrates associated with the canopies of Agarum cribrosum, Alaria esculenta, Desmarestia viridis and Ptilota serrata and for the abundance of invertebrates found on the algae and on the bottom separately

Ptilota serrata and only occasionally with Agarum cribrosum. The whelk Buccinum undatum was almost exclusively associated with $P$. serrata although it also occurs in habitats which were not sampled in this study (i.e. deeper soft-sediment habitats). Invertebrates associated with algal canopies also showed differences among habitats (Table 2). The herbivorous gastropods Margarites helicinus and Lacuna vincta were most abundant on A. esculenta and A. cribrosum fronds, and accounted for much of the dissimilarity between these kelps and the branched algae. A. cribrosum was further characterized by the mussel Musculus corrugatus. P. serrata was characterized by the presence of the sea star Asterias vulgaris and a high abundance of the brittle star Ophiura robusta. Strongylocentrotus droebachiensis was most common in the P. serrata habitat 
Table 1. Species accounting for $75 \%$ of the dissimilarity (listed in order of importance) between 2 habitats in invertebrate communities on the bottom. *indicates in which of the 2 habitats the species was most abundant, i.e. species with an asterisk were more abundant in the habitat given at the top of the table

\begin{tabular}{|c|c|c|c|c|}
\hline & Agarum cribrosum* & Alaria esculenta* & Desmarestia viridis* & Ptilota serrata* \\
\hline $\begin{array}{l}\text { Alaria } \\
\text { esculenta }\end{array}$ & Mytilus edulis & & & \\
\hline $\begin{array}{l}\text { Desmarestia } \\
\text { viridis }\end{array}$ & $\begin{array}{l}\text { Tonicella marmorea } \\
\text { Ophiopholis aculeata } \\
\text { Hiatella arctica } \\
\text { Strongylocentrotus } \\
\text { droebachiensis* }\end{array}$ & M. edulis* & & \\
\hline $\begin{array}{l}\text { Ptilota } \\
\text { serrata }\end{array}$ & $\begin{array}{l}\text { O. aculeata* } \\
\text { Ophiura robusta } \\
\text { T. marmorea* } \\
\text { S. droebachiensis* } \\
\text { Pectinaria gouldii } \\
\text { Musculus discors laevigatus } \\
\text { M. edulis } \\
\text { H. arctica* } \\
\text { Buccinum undatum } \\
\text { Terebellidae }\end{array}$ & M. edulis* & $\begin{array}{l}\text { T. marmorea* } \\
\text { H. arctica* } \\
\text { O. robusta } \\
\text { O. aculeata* } \\
\text { P. gouldii } \\
\text { Polynoidae } \\
\text { S. droebachiensis* }\end{array}$ & \\
\hline Barrens & $\begin{array}{l}\text { O. robusta } \\
\text { O. aculeata* } \\
\text { S. droebachiensis } \\
\text { T. marmorea } \\
\text { H. arctica }\end{array}$ & M. edulis* & $\begin{array}{l}\text { O. robusta } \\
\text { O. aculeata } \\
\text { T. marmorea* } \\
\text { H. } \text { arctica }^{*}\end{array}$ & $\begin{array}{l}\text { O. robusta } \\
\text { T. marmorea } \\
\text { S. droebachiensis } \\
\text { O. aculeata* } \\
\text { H. arctica } \\
\text { M. discors laevigatus* } \\
\text { P. gouldii* }\end{array}$ \\
\hline
\end{tabular}

Table 2. Species accounting for $75 \%$ of the dissimilarity (listed in order of importance) between habitats in invertebrates on algal fronds. *indicates in which of the 2 habitats the species was most abundant

\begin{tabular}{|c|c|c|c|}
\hline & Agarum cribrosum* & Alaria esculenta* & Desmarestia viridis* \\
\hline $\begin{array}{l}\text { Alaria } \\
\text { esculenta }\end{array}$ & $\begin{array}{l}\text { Margarites helicinus* } \\
\text { Lacuna vincta }\end{array}$ & & \\
\hline $\begin{array}{l}\text { Desmarestia } \\
\text { viridis }\end{array}$ & $\begin{array}{l}\text { M. helicinus* } \\
\text { L. vincta* }\end{array}$ & $\begin{array}{l}\text { M. helicinus* } \\
\text { L. vincta* }\end{array}$ & \\
\hline $\begin{array}{l}\text { Ptilota } \\
\text { serrata }\end{array}$ & $\begin{array}{l}\text { M. helicinus* } \\
\text { Ophiura robusta } \\
\text { Musculus discors laevigatus } \\
\text { Musculus corrugatus* }\end{array}$ & $\begin{array}{l}\text { O. robusta } \\
\text { M. helicinus* } \\
\text { L. vincta* } \\
\text { Strongylocentrotus } \\
\text { droebachiensis }\end{array}$ & $\begin{array}{l}\text { O. robusta } \\
\text { M. discors laevigatus } \\
\text { Asterias vulgaris } \\
\text { S. droebachiensis }\end{array}$ \\
\hline
\end{tabular}

but was the only invertebrate found in abundance on the fronds of $D$. viridis. (Caprellid amphipods were also observed in high abundance on $D$. viridis [as well as on A. cribrosum] but were excluded from the analyses because of the difficulties in sampling them.)

The univariate analyses, applied to all species that accounted for $>2 \%$ dissimilarity between any 2 habitats, showed significant differences in abundance between habitats for almost every species analyzed (Table 3) and provided further support for the trends indicated by the SIMPER routine (Tables $1 \& 2$ ). In the analysis of invertebrates on the bottom, Mytilus edulis was characteristic of the Alaria esculenta habitat, and Strongylocentrotus droebachiensis occurred in highest densities in urchin barrens. Ophiopholis aculeata, Tonicella marmorea and Hiatella arctica were all found in 
Table 3. Results of 1-way ANOVA applied to ranked data for the abundance of invertebrates on the bottom and on the algae, followed by Ryan tests, to compare the communities associated with the macroalgae Agarum cribrosum, Alaria esculenta, Desmarestia viridis and Ptilota serrata and on urchin barrens. Habitats not sharing the same letter significantly differ in abundance. For all analyses of invertebrates on the bottom $\mathrm{df}_{\text {treatment }}=4, \mathrm{df}_{\text {error }}=43$. For all analyses of invertebrates on algae: $\mathrm{df}_{\text {treatment }}=3$, $\mathrm{df}_{\text {error }}=31$

\begin{tabular}{|c|c|c|c|c|c|c|c|}
\hline & $F$ & $\mathrm{p}$ & $\begin{array}{l}\text { Agarum } \\
\text { cribrosum }\end{array}$ & $\begin{array}{c}\text { Alaria } \\
\text { esculenta }\end{array}$ & $\begin{array}{l}\text { Urchin } \\
\text { barrens }\end{array}$ & $\begin{array}{c}\text { Desmarestia } \\
\text { viridis }\end{array}$ & $\begin{array}{l}\text { Ptilota } \\
\text { serrata }\end{array}$ \\
\hline \multicolumn{8}{|c|}{ Invertebrates on the bottom } \\
\hline Asterias vulgaris & 17.42 & 0.0001 & $\mathrm{a}$ & $\mathrm{b}$ & $\mathrm{b}$ & $\mathrm{a}$ & $\mathrm{a}$ \\
\hline Buccinum undatum & 5.81 & 0.0008 & $\mathrm{~b}$ & $\mathrm{ab}$ & $\mathrm{b}$ & $\mathrm{b}$ & a \\
\hline Chiridota laevis & 3.24 & 0.021 & $\mathrm{ab}$ & $\mathrm{b}$ & $\mathrm{ab}$ & $a b$ & a \\
\hline Hiatella arctica & 16.11 & 0.0001 & $\mathrm{C}$ & $\mathrm{C}$ & $\mathrm{b}$ & $\mathrm{a}$ & $\mathrm{C}$ \\
\hline Margarites helicinus & 3.18 & 0.022 & $a b$ & a & $\mathrm{ab}$ & $\mathrm{b}$ & $\mathrm{ab}$ \\
\hline Musculus corrugatus & 5.92 & 0.0007 & $\mathrm{a}$ & $\mathrm{b}$ & $\mathrm{b}$ & $\mathrm{b}$ & $\mathrm{ab}$ \\
\hline M. discors laevigatus & 19.59 & 0.0001 & $\mathrm{~b}$ & bc & c & bc & $\mathrm{a}$ \\
\hline Mytilus edulis & 19.42 & 0.0001 & $\mathrm{bc}$ & $\mathrm{a}$ & c & bc & $\mathrm{b}$ \\
\hline Ophiura robusta & 48.08 & 0.0001 & $\mathrm{C}$ & $\mathrm{C}$ & $\mathrm{b}$ & $\mathrm{a}$ & a \\
\hline Ophiopholis aculeata & 31.97 & 0.0001 & $\mathrm{bc}$ & $\mathrm{d}$ & $\mathrm{C}$ & $\mathrm{a}$ & $\mathrm{b}$ \\
\hline Pectinaria gouldii & 2.97 & 0.030 & $\mathrm{ab}$ & $\mathrm{b}$ & $\mathrm{ab}$ & $\mathrm{ab}$ & $\mathrm{a}$ \\
\hline Polynoidae & 7.68 & 0.0001 & bc & $\mathrm{ab}$ & bc & $\mathrm{a}$ & C \\
\hline Sabellidae & 1.85 & 0.14 & & & & & \\
\hline \multicolumn{8}{|l|}{ Strongylocentrotus } \\
\hline droebachiensis & 8.63 & 0.0001 & $\mathrm{~b}$ & $\mathrm{C}$ & a & bc & bc \\
\hline Terebellidae & 0.44 & 0.78 & & & & & \\
\hline Tonicella marmorea & 26.79 & 0.0001 & bc & $\mathrm{d}$ & $\mathrm{b}$ & a & c \\
\hline \multicolumn{8}{|c|}{ Invertebrates on algal fronds } \\
\hline Asterias vulgaris & 46.23 & 0.0001 & $\mathrm{~b}$ & $\mathrm{C}$ & - & $\mathrm{C}$ & a \\
\hline Lacuna vincta & 92.85 & 0.0001 & $\mathrm{~b}$ & a & - & c & C \\
\hline Margarites helicinus & 83.01 & 0.0001 & a & $\mathrm{b}$ & - & C & $\mathrm{C}$ \\
\hline Musculus corrugatus & 9.40 & 0.0001 & a & $\mathrm{b}$ & - & $\mathrm{b}$ & $\mathrm{ab}$ \\
\hline M. discors laevigatus & 42.82 & 0.0001 & $\mathrm{~b}$ & $\mathrm{~b}$ & - & $\mathrm{b}$ & $\mathrm{a}$ \\
\hline Mytilus edulis & 9.49 & 0.0001 & $\mathrm{~b}$ & $\mathrm{~b}$ & - & $\mathrm{b}$ & $\mathrm{a}$ \\
\hline Ophiura robusta & 453.9 & 0.0001 & $\mathrm{~b}$ & $\mathrm{~b}$ & - & $\mathrm{b}$ & a \\
\hline Ophiopholis aculeata & 4.53 & 0.0096 & $\mathrm{a}$ & $\mathrm{b}$ & - & $\mathrm{ab}$ & a \\
\hline \multicolumn{8}{|l|}{ Strongylocentrotus } \\
\hline droebachiensis & 21.01 & 0.0001 & $\mathrm{~b}$ & C & - & $\mathrm{b}$ & a \\
\hline
\end{tabular}

highest numbers under Desmarestia viridis. Scaleworms (Polynoidae) were more abundant under D. viridis and $A$. esculenta than in the Ptilota serrata habitat. $P$. serrata sheltered the highest abundances of Musculus discors laevigatus and Buccinum undatum. M. corrugatus was most abundant under Agarum cribrosum and P. serrata (Table 3 ).

For invertebrates found on algal fronds, Lacuna vincta was found in significantly higher abundance on Alaria esculenta than on Agarum cribrosum, whereas the opposite was observed for Margarites helicinus. Both gastropods were almost completely absent from the other 2 algae. Ptilota serrata sheltered, however, high abundances of other invertebrates, with significantly higher densities of Ophiura robusta, Asterias vulgaris (small individuals), Musculus discors laevigatus, Strongylocentrotus droebachiensis and Mytilus edulis than in the other habitats. $P$. serrata was the only alga on which mussels occasionally occurred directly on the fronds.

\section{Effect of canopy removal on mussel growth and recruitment}

Mussels Mytilus edulis showed differences among treatments in increases of both weight $\left(F_{4,12}=14.02\right.$; $\mathrm{p}=0.0002)$ and length $\left(F_{4,12}=4.85 ; \mathrm{p}=0.014 ;\right.$ Fig. 3$)$. Mussel growth was higher in Alaria esculenta zone than in the Agarum cribrosum zone for both weight ( $p<0.0001)$ and length ( $p=0.001$; Fig. 3 ). Within the A. esculenta zone, growth in weight of mussels tended to be greater inside than outside the canopy, but the difference was not significant ( $p=0.26$ ).

Recruitment of Mytilus edulis differed among treatments $\left(F_{4,23}=4.04 ; \mathrm{p}=0.0127\right)$, being higher in the Alaria esculenta zone than the Agarum cribrosum zone ( $p=0.004$; Fig. 3). Within the A. esculenta zone, mussel recruitment was 7 -fold higher under the canopy (Fig. 3), but this difference was not significant, probably because of the large variation observed among replicates and the loss of several experimental units. 

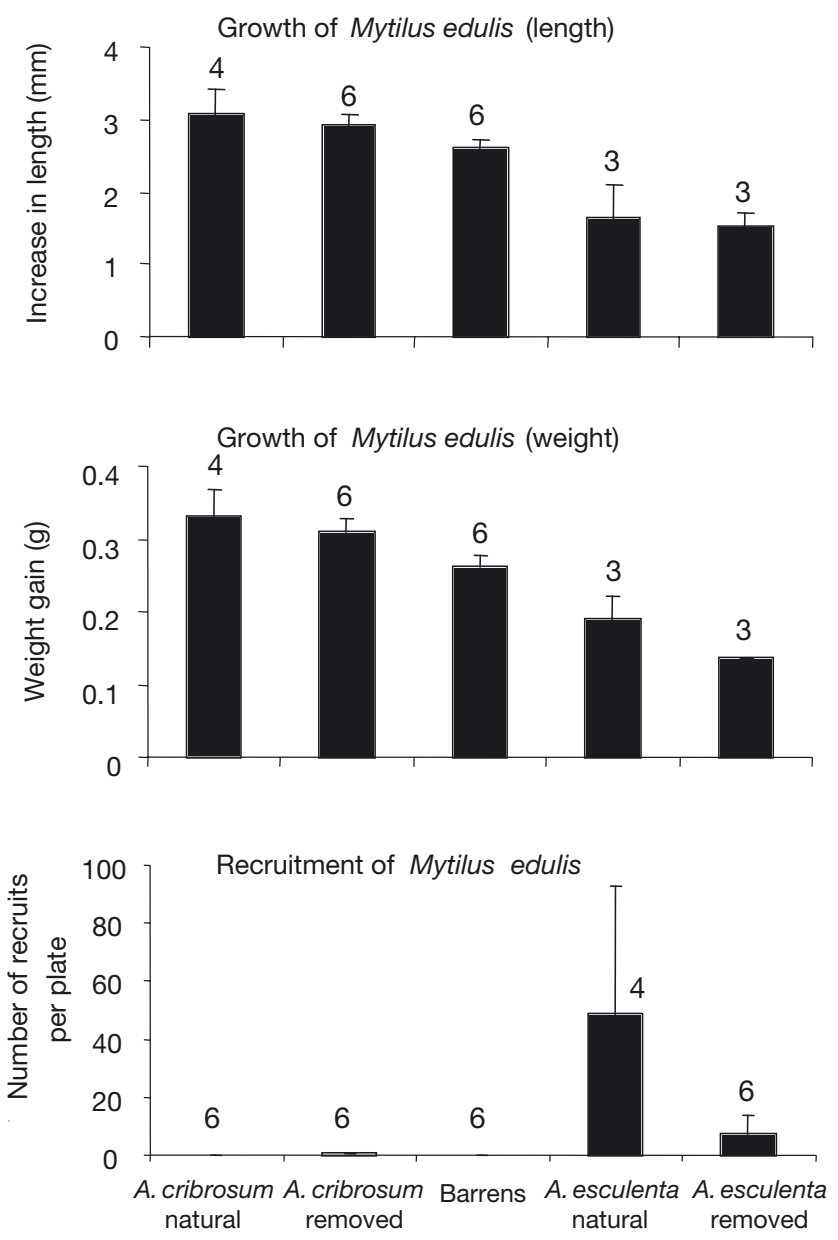

Fig. 3. Increase in shell length and wet weight (from 13 July to 30 October 2001) and number of recruits per plate for the mussel Mytilus edulis under the canopy of the macroalgae Agarum cribrosum and Alaria esculenta in experimental plots where the canopy was removed, and on urchin barrens. Vertical bars represent SEs; sample sizes shown over each bar

Water velocity was higher in the macroalgal removal treatments than in the controls with canopy in the same habitat (18 times higher for the Alaria esculenta habitat; 6 times higher for the Agarum cribrosum habitat). Velocities measured in canopy removal treatments were twice as high in the $A$. esculenta zone than the $A$. cribrosum zone (4.9 vs $2.6 \mathrm{~cm} \mathrm{~s}^{-1}$, respectively). In contrast, velocities measured under canopies were similar between the 2 zones ( 0.3 and $0.4 \mathrm{~cm} \mathrm{~s}^{-1}$, respectively). However, these measurements were taken at slack tide on a day with weak currents, and greater differences may exist when mainstream current velocities are higher.

\section{DISCUSSION}

\section{Invertebrates in algal habitats and urchin barrens}

Distinct invertebrate communities were associated with each of the habitats we sampled, for both invertebrates on the algae and on the bottom. This pattern is consistent with previous studies that have examined the effect of the physical structure provided by aquatic plants (Kennelly 1989, Eckman \& Duggins 1991, Irlandi \& Peterson 1991) and underscores the importance of macroalgae as autogenic 'ecosystem engineers' (sensu Jones et al. 1994) in marine benthic communities. Our results go beyond earlier studies in that we investigated the effects of several structurally complex macrophytes on a wide variety of invertebrate taxa, occurring both on the algae themselves and on the underlying substratum. We demonstrated differences in the invertebrate communities associated with the various types of algal patches, which were likely attributable to the physical and life-history characteristics of the algae. Surprisingly, the presence of a canopy did not necessarily result in an increased diversity of invertebrates as the lowest index of diversity occurred in the Alaria esculenta habitat and was less than a third of that seen in the perhaps misnamed 'barrens', supporting the idea that the relationship between diversity and productivity is not simple (e.g. Kassen et al. 2000, Worm \& Duffy 2003).

The use of a combination of multivariate and univariate statistical analyses, as well as a stratified sampling strategy at the community-level, allowed us to determine the precise nature of the differences we observed, both in terms of the physical location (i.e. bottom vs canopy) and the species involved. Thus, the distinctive nature of the Alaria esculenta habitat was due primarily to the different composition of the invertebrates on the bottom, and more specifically to the abundance of the mussel Mytilus edulis. In contrast, differences among the deeper habitats were mostly due to differences in the invertebrates on the algae, and to a lesser extent to differences in the invertebrates on the bottom. The differences between different canopy types could again be ascribed to particular species (e.g. Ophiura robusta and Musculus discors laevigatus on Ptilota serrata).

The differences between algal types are likely attributable to the characteristics of the algae, including their size, morphology, and longevity. The invertebrate communities on the blades of Alaria esculenta and Agarum cribrosum were similar (dominated by herbivorous gastropods), yet quite different from those on the branched algae, Desmarestia viridis and Ptilota serrata. An increase in macroinvertebrate abundance with plant architectural complexity has been observed 
for many freshwater (Krecker 1939, Cheruvelil et al. 2000) and marine (Heck \& Wetstone 1977, Dean \& Connell 1987a,b,c, Hacker \& Steneck 1990, Taylor \& Cole 1994) invertebrates, and we observed higher densities of a number of invertebrates inhabiting the highly-branched fronds of $P$. serrata. The structural complexity (high frond density and branching nature) and longevity of $P$. serrata may provide invertebrates both a spatial and temporal opportunity for shelter. Moreover, the turf-like habit of $P$. serrata should provide easy access to certain invertebrates crawling onto it from the surrounding substratum.

In contrast, Desmarestia viridis fronds always supported a low diversity of invertebrates in spite of their high morphological complexity. Urchins (mostly juveniles) and caprellid amphipods were the only species regularly found on this alga. This low diversity was probably due simply to the short duration of this stage of the life cycle. Sporophytes appear and grow rapidly during the winter, and disappear during the summer and early autumn. The wave-induced sweeping movement of $D$. viridis is another factor that could explain the low number of invertebrates on its fronds. Because of its delicate, highly filamentous structure, $D$. viridis moves with even the slightest water movement, and urchins are repulsed when touched by moving $D$. viridis fronds (Himmelman 1984, Konar 2000, Gagnon et al. 2003a). Indeed, the small urchins found on $D$. viridis in our study may have simply been entangled in the fronds as they swept over the bottom. Finally, the low diversity of invertebrates may be due to the sulfuric acid contained in the tissue of this alga (McClintock et al. 1982), but this characteristic should not affect non-consumers, and its impact on consumers remains unclear (Himmelman \& Nélélec 1990, Konar 2000).

The comparison of invertebrates on the bottom in the 5 habitats showed that the community under Alaria esculenta differed markedly from that in the other habitats. The mussel Mytilus edulis was always present in high densities, but the overall index of invertebrate diversity was low. Moreover, mussel beds are almost exclusively found under A. esculenta (Gaymer \& Himmelman 2002). Although depth was confounded with the type of canopy in our sampling design (other canopy habitats were all deeper than the A. esculenta habitat, and barrens were not found within the A. esculenta zone), the association of $M$. edulis with A. esculenta seems to be more than a direct effect of depth. Mussel beds do not regularly occur in any other habitat, even in the barrens immediately below the A. esculenta zone. Our data are consistent with the study of Gaymer et al. (2001), which showed that mussels are limited to shallow depths and that their abundance is negatively correlated with the abundance of their primary predators, the sea stars Asterias vulgaris and Leptasterias polaris. The ultimate cause of this correlation may be the refuge $A$. esculenta provides from sea star predation resulting from the sweeping of its fronds. Much like urchins (e.g. Konar 2000, Gagnon et al. 2003a), sea stars appear to avoid contact with moving algal fronds (Gagnon et al. 2003b).

The invertebrate community on the bottom differed to a lesser extent among the 4 deeper habitats that were approximately at the same depth (barrens, Desmarestia viridis, Ptilota serrata and Asgarum cribrosum). As expected, urchin barrens were characterized by the highest densities of the urchin. In the multidimensional scaling plots (Fig. 2), the samples from the $D$. viridis habitat form a tight group of points surrounded by points for the urchin barrens habitat. This clustering may simply represent a short-term modification of the urchin barrens' assemblage as the short life-span of $D$. viridis may preclude more dramatic shifts. Nevertheless, the presence of $D$. viridis significantly increased the abundance of 6 species of invertebrates (the brittle stars Ophiopholis aculeata and Ophiura robusta, the sea star Asterias vulgaris, the chiton Tonicella marmorea, the burrowing clam Hiatella arctica and scaleworms [Polynoidae]) compared to adjacent barrens zones. Possibly, the reduced abundance of urchins under $D$. viridis (this study, Gagnon et al. 2003a) increases the survival of some of these invertebrates.

The brittle star Ophiura robusta, the mussel Musculus discors laevigatus and the whelk Buccinum undatum characterized the community under Ptilota serrata. $M$. discors laevigatus occurred almost exclusively in association with $P$. serrata, usually tangled in its filamentous holdfasts. The highest densities of whelks were found in the $P$. serrata habitat, but almost all were juveniles, suggesting it provides an important refuge for juvenile whelks until they move to adjacent softbottom habitats (Himmelman 1991).

\section{Effect of canopy removal on mussel growth and recruitment}

Growth rates of Mytilus edulis in our study were comparable to those reported in other subtidal environments (Leichter \& Witman 1997, Archambault et al. 1999, Littorin \& Gilek 1999). The high growth rate of mussels in the Agarum cribrosum zone is surprising considering that mussels are normally absent in this habitat. The decreased growth of mussels in the Alaria esculenta zone could be due to a number of reasons, including food depletion from adjacent mussel beds (Fréchette \& Bourget 1985b, Littorin \& Gilek 1999) and reduced feeding efficiency (i.e. ability to pump water) due to flow effects (Fréchette \& Bourget 1985a, Newell et al. 2001). 
The absence of mussel beds in the Agarum cribrosum zone, a habitat that is better for growth, could be explained in 2 ways: mussels are either excluded from deeper waters by predation or recruitment is low at greater depths. Certainly, predation on mussels by sea stars is intensive in the A. cribrosum zone (Gaymer et al. 2001, Gaymer \& Himmelman 2002), and the abundant sea urchins in this zone can also prey on small mussels (Himmelman \& Steele 1971, Himmelman et al. 1983, Briscoe \& Sebens 1988). Recruitment patterns of Mytilus edulis are consistent with the second hypothesis as recruitment matched the adult distribution. The higher recruitment of Mytilus edulis in shallower water is consistent with previous studies (Littorin \& Gilek 1999), but unfortunately our experimental design did not allow us to determine whether differences in larval settlement (e.g. onto to filamentous algae or the byssal threads of adult mussels), post-settlement translocation from adjacent mussel beds, or post-settlement mortality due to deeper predators (e.g. sea stars and urchins) were responsible for the recruitment patterns observed.

Our study illustrates the important link between algal canopies and invertebrate assemblages, with distinct invertebrate communities associated with the canopies of different macroalgae and with urchin barrens. As expected, differences existed in the invertebrates associated with the canopies, but beyond this direct effect, differences were also observed for invertebrates on the bottom. Even Desmarestia viridis, an ephemeral alga present in small patches only for part of the year, increased the abundance of 6 species of invertebrates relative to adjacent urchin barrens, possibly by providing a refuge from predators. Likewise, the tight association between Mytilus edulis and Alaria esculenta may exist because this canopy provides favorable conditions for settlement and a refuge from sea star predation. Further studies, such as laboratory experiments and transplantation experiments, are needed to elucidate the exact causes of the observed associations between invertebrates and algae. This knowledge will, in turn, allow better prediction of the impacts of anthropogenic and natural disturbances on species diversity, abundance and distribution in this ecosystem.

Acknowledgements. We thank C. Dumont, M. Thompson, A. Drouin, D. Drolet, G. Wagner, M.-O. Nadon, I. Deschênes, C. Vallières, and S.-P. Gingras for assistance during field work, and P. Archambault and 4 anonymous reviewers for useful criticism on earlier versions of this paper. This research was supported by NSERC and FCAR grants to L.E.J. and J.H.H. and by a grant from Project Aware to C.B. C.B. was supported by post-graduate scholarships from NSERC, Fisheries and Oceans Canada, and Québec-Océan.

\section{LITERATURE CITED}

Archambault P, Bourget E (1999) Influence of shoreline configuration on spatial variation of meroplanktonic larvae, recruitment and diversity of benthic subtidal communities. J Exp Mar Biol Ecol 238:161-184

Archambault P, McKindsey CW, Bourget E (1999) Large-scale shoreline configuration influences phytoplankton concentration and mussel growth. Estuar Coast Shelf Sci 49: 193-208

Bégin C (2002) Invertebrate communities in the Gulf of St. Lawrence: influence of algal canopies on recruitment and growth. MSc thesis, Université Laval

Bertness MD, Callaway R (1994) Positive interactions in communities. Trends Ecol Evol 9:191-193

Bertness MD, Leonard GH (1997) The role of positive interactions in communities: lessons from the intertidal habitats. Ecology 78:1976-1989

Bertness MD, Leonard GH, Levine JM, Schmidt PR, Ingraham AO (1999) Testing the relative contribution of positive and negative interactions in rocky intertidal communities. Ecology 80:2711-2726

Briscoe CS, Sebens KP (1988) Omnivory in Strongylocentrotus droebachiensis (Müller) (Echinodermata: Echinoidea): predation on subtidal mussels. J Exp Mar Biol Ecol 115: $1-24$

Bulleri F, Benedetti-Cecchi L, Acunto S, Cinelli F, Hawkins SJ (2002) The influence of canopy algae on vertical patterns of distribution of low-shore assemblages on rocky coasts in the northwest Mediterranean. J Exp Mar Biol Ecol 267: 89-106

Cheruvelil K, Soranno P, Serbin R (2000) Macroinvertebrates associated with submerged macrophytes: sample size and power to detect effects. Hydrobiologia 441:133-139

Clarke KR (1993) Non-parametric multivariate analyses of changes in community structure. Aust J Ecol 18:117-143

Conover WJ (1971) Practical nonparametric statistics. John Wiley \& Sons, New York

Day RW, Quinn GP (1989) Comparisons of treatments after an analysis of variance in ecology. Ecol Monogr 59:433-463

Dayton PK (1985) Ecology of kelp communities. Annu Rev Ecol Syst 16:215-245

Dayton PK, Currie V, Gerrodette T, Keller B, Rosenthal, Tresca DV (1984) Patch dynamics and stability of some California kelp communities. Ecol Monogr 54:253-289

Dean RL, Connell JH (1987a) Marine invertebrates in an algal succession. I. Variations in abundance and diversity with succession. J Exp Mar Biol Ecol 109:195-215

Dean RL, Connell JH (1987b) Marine invertebrates in an algal succession. II. Tests of hypotheses to explain changes in diversity with succession. J Exp Mar Biol Ecol 109: $217-247$

Dean RL, Connell JH (1987c) Marine invertebrates in an algal succession. III. Mechanisms linking habitat complexity with diversity. J Exp Mar Biol Ecol 109:249-273

Duffy JE, Hay ME (1991) Food and shelter as determinants of food choice by an herbivorous marine amphipod. Ecology 72:1286-1298

Duggins DO, Simenstad CA, Estes JA (1989) Magnification of secondary production by kelp detritus in coastal marine ecosystems. Science 245:170-173

Duggins DO, Eckman JE, Sewell AT (1990) Ecology of understory kelp environments. II. Effects of kelps on recruitment of benthic invertebrates. J Exp Mar Biol Ecol 143:27-45

Eckman JE (1983) Hydrodynamic processes affecting benthic recruitment. Limnol Oceanogr 28:241-257

Eckman JE, Duggins DO (1991) Life and death beneath 
macrophyte canopies: effects of understory kelps on growth rates and survival of marine, benthic suspension feeders. Oecologia 87:473-487

Fréchette M, Bourget E (1985a) Energy flow between the pelagic and benthic zones: factors controlling particulate organic matter available to an intertidal mussel bed. Can J Fish Aquat Sci 42:1158-1165

Fréchette M, Bourget E (1985b) Food-limited growth of Mytilus edulis L. in relation to the benthic boundary layer. Can J Fish Aquat Sci 42:1166-1170

Gagnon P, Himmelman JH, Johnson LE (2003a) Algal colonization in urchin barrens: defense by association during recruitment of the brown alga Agarum cribrosum. J Exp Mar Biol Ecol 290:179-196

Gagnon P, Wagner G, Himmelman JH (2003b) Use of a wave tank to study the effects of water motion and algal movement on the displacement of the sea star Asterias vulgaris towards its prey. Mar Ecol Prog Ser 258:125-132

Gagnon P, Himmelman JH, Johnson LE (2004) Temporal variation in community interfaces: kelp bed boundary dynamics adjacent to persistent urchin barrens. Mar Biol 144:1191-1203

Gaymer CF, Himmelman JH (2002) Mussel beds in deeper water provide an unusual situation for competitive interactions between the seastars Leptasterias polaris and Asterias vulgaris. J Exp Mar Biol Ecol 277:13-24

Gaymer CF, Himmelman JH, Johnson LE (2001) Distribution and feeding ecology of the seastars Leptasterias polaris and Asterias vulgaris in the northern Gulf of St Lawrence, Canada. J Mar Biol Assoc UK 81:827-843

Gilinsky E (1984) The role of fish predation and spatial heterogeneity in determining benthic community structure. Ecology 65:455-468

Hacker SD, Gaines SD (1997) Some implications of direct positive interactions for community species diversity. Ecology 78:1990-2003

Hacker SD, Steneck RS (1990) Habitat architecture and the abundance and body-size-dependent habitat selection of a phytal amphipod. Ecology 71:2269-2285

Heck KL, Wetstone GS (1977) Habitat complexity and invertebrate species richness and abundance in tropical seagrass meadows. J Biogeogr 4:135-142

Himmelman JH (1984) Urchin feeding and macroalgal distribution in Newfoundland, eastern Canada. Nat Can 111: 337-348

Himmelman JH (1991) Diving observations of subtidal communities in the northern Gulf of St. Lawrence. In: Therriault JC (ed) The Gulf of St. Lawrence: small ocean or big estuary? Can Spec Publ Fish Aquat Sci 113:319-332

Himmelman JH, Nédélec H (1990) Urchin foraging and algal survival strategies in intensely grazed communities in eastern Canada. Can J Fish Aquat Sci 47:1011-1026

Himmelman JH, Steele DH (1971) Foods and predators of the green sea urchin Strongylocentrotus droebachiensis in Newfoundland waters. Mar Biol 9:315-322

Himmelman JH, Cardinal A, Bourget E (1983) Community development following removal of sea urchins, Strongylocentrotus droebachiensis, from the rocky subtidal zone of the St. Lawrence Estuary, eastern Canada. Oecologia 59: 27-39

Irlandi EA, Peterson CH (1991) Modification of animal habitat by large plants: mechanisms by which seagrasses influence clam growth. Oecologia 87:307-318

Johnson CR, Mann KH (1993) Rapid succession in subtidal understorey seaweeds during recovery from overgrazing by sea urchins in eastern Canada. Bot Mar 36:63-77

Jones CG, Lawton JH, Shachak M (1994) Organisms as ecosystem engineers. Oikos 69:373-386

Jones CG, Lawton JH, Shachak M (1997) Positive and negative effects of organisms as physical ecosystem engineers. Ecology 78:1946-1957

Kassen R, Bucking A, Bell G, Rainey PB (2000) Diversity peaks at intermediate productivity in a laboratory microcosm. Nature 406:508-512

Keats DW, South GR, Steele DH (1985) Algal biomass and diversity in the upper subtidal at a pack-ice disturbed site in eastern Newfoundland. Mar Ecol Prog Ser 25: 151-158

Kennelly SJ (1987) Physical disturbances in an Australian kelp community. I. Temporal effects. Mar Ecol Prog Ser 40: 145-153

Kennelly SJ (1989) Effects of kelp canopies on understorey species due to shade and scour. Mar Ecol Prog Ser 50: $215-224$

Konar B (2000) Seasonal inhibitory effects of marine plants on sea urchins: structuring communities the algal way. Oecologia 125:208-217

Krecker FH (1939) A comparative study of the animal population of certain submerged aquatic plants. Ecology 20: $553-562$

Leichter JJ, Witman JD (1997) Water flow over subtidal rock walls: relation to distributions and growth rates of sessile suspension feeders in the Gulf of Maine-water flow and growth rates. J Exp Mar Biol Ecol 209:293-307

Littorin B, Gilek M (1999) Vertical patterns in biomass, size structure, growth and recruitment of Mytilus edulis in an archipelago area in the northern Baltic Sea proper. Ophelia 50:93-112

Lubchenco J, Gaines SD (1981) A unified approach to marine plant-herbivore interactions. I. Populations and communities. Annu Rev Ecol Syst 12:405-437

McClintock M, Higinbotham N, Uribe EG, Cleland RE (1982) Active, irreversible accumulation of extreme levels of $\mathrm{H}_{2} \mathrm{SO}_{4}$ in the brown alga, Desmarestia. Plant Physiol 70: 771-774

Menge BA (1978) Predation intensity in a rocky intertidal community. Oecologia 34:1-15

Newell CR, Wildish DJ, MacDonald BA (2001) The effects of velocity and seston concentration on the exhalant siphon area, valve gape and filtration rate of the mussel Mytilus edulis. J Exp Mar Biol Ecol 262:91-111

Peterson CH (1982) Clam predation by whelks (Busycon spp.): experimental tests of the importance of prey size, prey density, and seagrass cover. Mar Biol 66:159-170

Santelices B, Martinez EA (1988) Effects of filter-feeders and grazers on algal settlement and growth in mussel beds. J Exp Mar Biol Ecol 118:281-306

Scheibling RE (1986) Increased macroalgal abundance following mass mortalities of sea urchins (Strongylocentrotus droebachiensis) along the Atlantic coast of Nova Scotia. Oecologia 68:186-198

Scheibling RE, Hennigar AW, Balch T (1999) Destructive grazing, epiphytism, and disease: the dynamics of sea urchin-kelp interactions in Nova Scotia. Can J Fish Aquat Sci 56:2300-2314

Steinberg PD, de Nys R (2002) Chemical mediation of colonization of seaweed surfaces. J Phycol 38:621-629

Taylor RB, Cole RG (1994) Mobile epifauna on subtidal brown seaweeds in northeastern New Zealand. Mar Ecol Prog Ser 115:271-282

Velimirov B, Griffiths CL (1979) Wave-induced kelp movement and its importance for community structure. Bot Mar 22:169-172

Wildish DJ, Miyares MP (1990) Filtration rate of blue mussels 
as a function of flow velocity: preliminary experiments. J Exp Mar Biol Ecol 142:213-219

Witman JD (1987) Subtidal coexistence: storms, grazing, mutualism, and the zonation of kelps and mussels. Ecol Monogr 57:157-187

Editorial responsibility: Otto Kinne (Editor),

Oldendorf/Luhe, Germany
Worm B, Duffy JE (2003) Biodiversity, productivity and stability in real food webs. Trends Ecol Evol 18:628-632

Young M, Chia FS (1984) Microhabitat-associated variability in survival and growth of subtidal solitary ascidians during the first 21 days after settlement. Mar Biol 81:61-68

Submitted: January 6, 2003; Accepted: January 20, 2004 Proofs received from author(s): April 2, 2004 